\title{
Husband's knowledge, characteristics and participation in family planning
}

\author{
Suci Musvita Ayu, Liena Sofiana, Khafidhotul Amaliah
}

Faculty of Public Health, Universitas Ahmad Dahlan, Indonesia

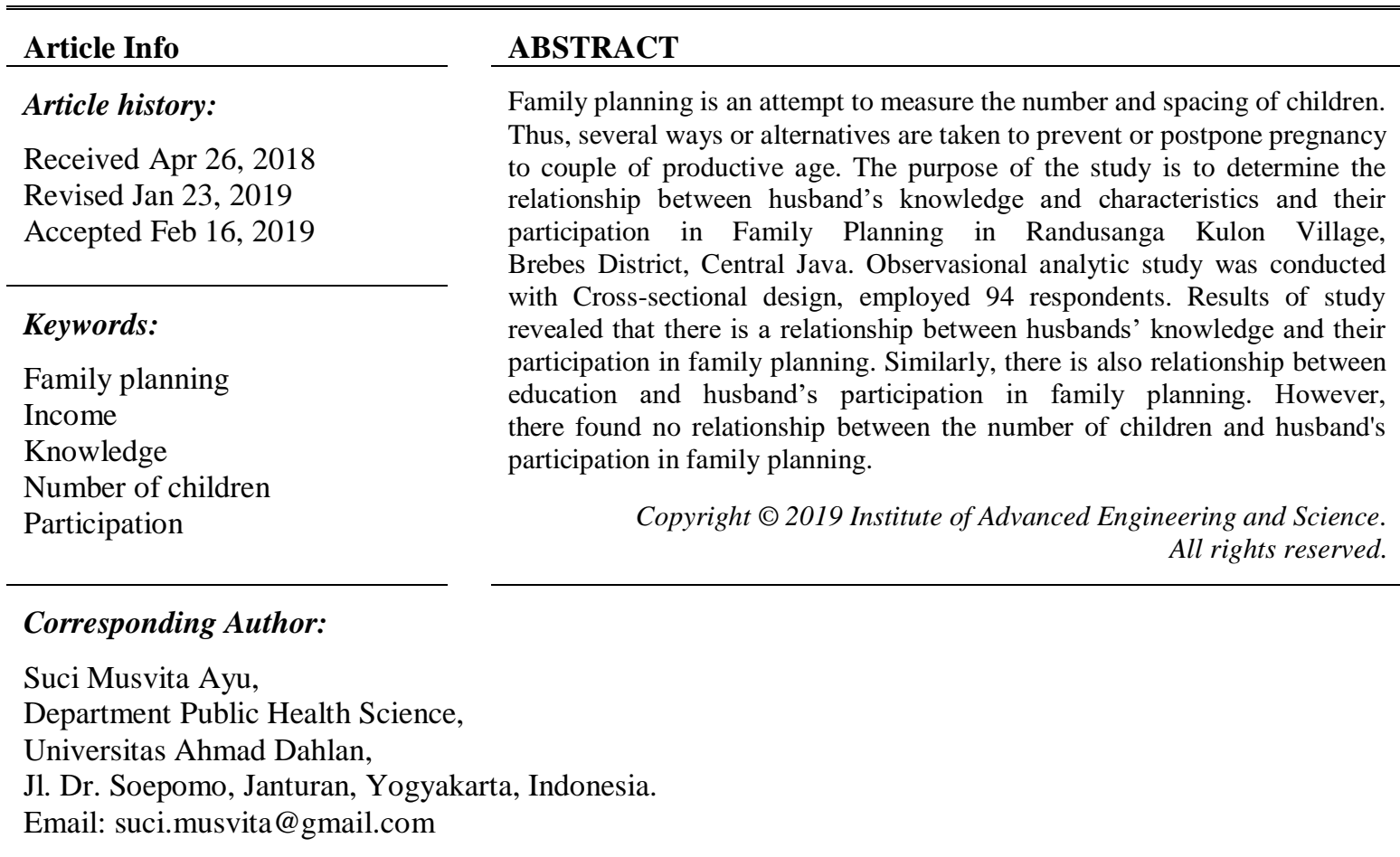

\section{INTRODUCTION}

Family Planning is an effort to measure the number and spacing of children. Thus, several ways or alternatives are taken to prevent or postpone pregnancy in Couple of Productive Age (CPA) [1]. The percentages of contraceptive being used are as follow: IUD 6.74\%, MOW 5.53\%, Implant 5.70\%, Injection $55.09 \%$, Pill 23.49\%, MOP $0.35 \%$, and Condom $3.11 \%$ [2]. To date, husbands' participation in Family Planning is still low [3]. In fact, knowledge on Family planning can be obtained through discussion between spouses about what contraceptives to be used. The information can also be gained through television, newspapers, magazines, etc [4]. Brebes District is within the objective range territory of Family Planning Program. The number of male participants in Family Planning is still low. It reached only 4000, or 1.5\%, of 263.043 participants in 2008 [5].

According to the development result, shown in the statistic publication of Brebes District in 2013, the number of Family Planning acceptor, based on the type of contraceptives, increases compared to the previous year. It reached 26.122 of acceptors, comprising of 2.122 of IUD user, 315 MOP, 2.263 MOW, 1.587 Implant, 14.548 injections, 5.033 Pill and 254 condoms [6]. Based on the local statistic of Brebes District in 2012, the acceptors of Family Planing in Randusanga village was zero. It means, no male participated in Family Planning, due to the absence of report on the number of Family Planning acceptor in the village. However, the number increased in 2013, up to 964 acceptors, comprising of 56 IUD acceptors, 0 MOP, $88 \mathrm{MOW}, 58$ Implants, 505 injections, 252 pills, and 5 acceptors of condom [7]. Therefore, the researcher aims to know the relation between husband's knowledge and characteristics and their participation in the family planning program. 


\section{RESEARCH METHOD}

This research belongs to analytic observational type, with Cross-sectional design. The samples are taken using random sampling techniques. The study was located in Randusanga Kulon V illage, Brebes District, Central Java, in March to April. The interview results conducted to the midwife of the area shows that the family planning acceptor is still low, especially the male. Using the formula, the study obtained 94 respondents [9].

\section{RESULTS AND DISCUSSION}

\subsection{Research result}

Distribution of Age, Knowledge, Education, and Number of Children of the Male Acceptor of Family Planning are shown in Table 1. Table 1 describes that there are 50 respondents, ranged from 26 to 36 years old (53.2\%). Based on the level of knowledge, 65 respondents are found to be in poor category (71.6\%). Based on the education level, 62 are from low level $(66 \%)$. Among the respondents, 83 of them are found to have few children $(88 \%)$. As for the male participation in family planning acceptor, 89 of them are not acceptor $(94.7 \%)$.

Table 1. Distribution of age, knowledge, education, and number of children of

\begin{tabular}{|c|c|c|}
\hline Category & Number & Percentage (\%) \\
\hline \multicolumn{3}{|l|}{ Age (Years) } \\
\hline $15-25$ & 3 & 3.2 \\
\hline $26-36$ & 50 & 53.2 \\
\hline Older than 37 & 41 & 43.6 \\
\hline \multicolumn{3}{|l|}{ Knowledge } \\
\hline Poor & 65 & 69.1 \\
\hline Good & 29 & 30.9 \\
\hline \multicolumn{3}{|l|}{ Education } \\
\hline Low & 62 & 66 \\
\hline High & 32 & 34 \\
\hline \multicolumn{3}{|l|}{ Number of Children } \\
\hline Many & 11 & 11.7 \\
\hline Few & 83 & 88.3 \\
\hline \multicolumn{3}{|c|}{ Husbands' participation as acceptor of family planning } \\
\hline Join & 89 & $94.7^{\circ}$ \\
\hline Not joining & 5 & 5.3 \\
\hline Total & 94 & 100 \\
\hline
\end{tabular}

The Relations between knowledge, education, as well as number of children and husbands' participation in family planning are shown in Table 2. Based on Table 2, fisher exact test revealed, the value obtained is $\mathrm{p}=0.030(\mathrm{p}<0.05)$. From the results, it can be concluded that there is a relation between husbands' knowledge and their participation in family planning. From the value of ratio prevalence (RP), which is 1.142 (CI 95\%=0.9841.325), it can be seen that the variable being studied is not a risk factor of husbands' participation as family planning acceptor. In education variable, the score is $\mathrm{p}=0.044(\mathrm{p}<0.05)$. It means that, statistically, there is a relation between husbands' education level and their participation in family planning in Randusanga Kulon village, Brebes sub-district, Central Java. From the value of Ratio Prevalence (RP), which is 1.124 (CI 95\%=0.983-1.287), we can see that the variable being studied is not the risk factor of husbands' participation as family planning acceptor. On the number of the children, the value is $\mathrm{p}=0.103$ $(\mathrm{p}>0.05)$. It is assumed that there is no significant relation between the number of the children and husbands' participation in family planning implemented in the village. From the value of Ratio Prevalence (RP), which is 0.0849 (CI 95\%=0.640-1.125), it is seen that the factor being studied minimize the occurrence of diseases. In other words, the variable being studied is protective factor. It shows that the number of the children is not a risk factor.

Int. J. Public Health Sci. Vol. 8, No. 1, March 2019: $31-35$ 
Table. 2. The Relations between knowledge, education, as well as number of children and husbands' participation in family planning

\begin{tabular}{ccccccc}
\hline Variable & \multicolumn{2}{c}{ Participation in } & & \multirow{2}{*}{ P- } & RP & CI \\
& Fomily Planning & Total & Value & & \\
\hline Knowledge & 64 & 1 & 65 & & & \\
Not good & 25 & 4 & 29 & 0.030 & 1.142 & $0.984-$ \\
Good & 89 & 5 & 94 & & & 1.325 \\
Total & 64 & 1 & 65 & & & \\
Education & 28 & 4 & 29 & 0.044 & 1.124 & $0.984-$ \\
Low & 89 & 5 & 94 & & & 1.287 \\
High & & & & & & \\
Total & 9 & 2 & 11 & & & $0.640-$ \\
Many & 80 & 3 & 83 & 0.103 & 0.849 & 1.125 \\
Few & 89 & 5 & 94 & & & \\
Total & & & & & &
\end{tabular}

\subsubsection{Multivariate analysis}

Results of logistic regression multivariate analysis are shown in Table 3. Based on Table 3, the results of logistic regression analysis, in step 2, shows that knowledge influences husbands' participation in family planning. The strength can be seen from the value of OR (EXP[ $\beta])$, which is $0.098(0.010-0.917)$.

Table 3. Results of logistic regression multivariate analysis

\begin{tabular}{ccccc}
\hline & Variable & Coefficient & $p$ & OR (CI 95\%) \\
\hline \multirow{4}{*}{ Step 1 } & Knowledge & -1.858 & 0.128 & $0.516(0.014-1.1711)$ \\
& Education & -1.472 & 0.228 & $0.229(0.21-2.507)$ \\
& Number of Children & 1.691 & 0.119 & $5.427(0.648-45.427)$ \\
\multirow{2}{*}{ Step 2 } & Constant & -1.792 & 0.010 & 0.0167 \\
& Knowledge & -2.326 & 0.042 & $0.098(0.010-0.917)$ \\
& Constant & -1.833 & 0.001 & 0160 \\
\hline
\end{tabular}

\subsection{Discussion}

\subsubsection{The relations between husbands' knowledge and their participation in family planning}

Based on the research results, the significant value is $0.030(\mathrm{p}<0.05)$, which means that there is significant relation, statistically, between husbands' knowledge and their participation in family planning. The value of Ration Prevalent (RP) is 1.142 (CI 95\%=0.984-1.325), showing that the variable being studied is not a risk factor of husbands' participation as the acceptor in family planning. In fact, husbands have not obtained enough information (knowledge) about family planning. Further, the societies in general are not aware in finding the information in the mass media. However, respondents' knowledge has positive influence on male participation in family planning. Viewed from the results of the research, it can be seen that the higher is the knowledge about family planning, the more these male respondents will be eager to participate in the program.

Participation in family planning is influenced by several factors. One of them is knowledge. Based on the research in South Kefamenanu, Timor Tengah Utara Regency, it is found that the higher is the knowledge, the higher is the participation in family planning [9]. Similarly, there is a relation between knowledge, husbands' support and their participation in family planning implemented in RW III Korong Gadang, within the range area of Community Health Center of Kuranji, Padang, in 2012 [10]. The results are supported with the results of research hypothesis test, with the value of $\mathrm{X} 2=7.534 \mathrm{p}=0.023$. It means there a relation between husbands' knowledge on family planning and their attitude on family planning implemented in Mrisen Village, Juwiring, Klaten [11].

The results are also in line with the theory stating that knowledge influences human's insight on shaping their attitude. It is followed by their taking action in the efforts to improve their health [12]. Those with little knowledge on family planning tend not to participate in the program. One of the ways to improve their knowledge, especially on contraceptives, is through family planning education [13]. Low participation on the husband side is also influenced by their perception that participating in the program will lower their pride in such a way. Indeed, they thought that family planning should only be taken by their wives.

The results of this study is also relevant with the research conducted by Ahmad (2009) with the $p$ value $=0.000$ and Sariyono et al (2007) with the $p$ value $=0.000$, meaning that knowledge influence husbands' participation in family planning $[14,15]$. However, this research is not in accordance with the results of 
a research showing that there is no relation between husbands' knowledge and their participation in the vasectomy program, with the $\mathrm{p}$ value $=0.054$ [16].

\subsubsection{Relation between husbands' education and their participation in family planning}

Based on the bivariate results, the value is $0.044(\mathrm{p}<0.05)$. It shows that, statistically, there is significant relation between husbands' education and their participation in family planning. The ratio prevalent (RP) is 1.124 (CI 95\%-0.983-1.287). It means that the variable being studied is not the risk factor of husbands' participation as acceptor of family planning.

Participation in family planning are influenced by several factors. One of them is the level of education. It is said that education is the determinant factor in the perception of new ideas/technology [9]. The higher is individual's education, the higher is the participation. The level of the respondents' participation is high. It is evident in the number of respondents participating in the family planning. Many of them are those having higher level of education, for they obtain more knowledge on the program from the mass media or during their study. Besides, the interventions also involve communication between spouses and the use of contraceptives. Education also provides practical information about how to use the contraceptives [17]. However, different result is obtained when the study was conducted to colored people. It is due to their lack of education about birth control and formal information about family planning [18].

\subsubsection{The relation between the number of children and husbands' participation in family planning}

Based on the bivariate analysis, the significant value is 0.103 ( $>0.05)$. It shows that, statistically, there is no significant relation between the number of children and husband's participation in family planning. The Prevalent Ratio is $0.0849(\mathrm{Cl} 95 \%=0.640-1.125)$, means that the analyzed factor can decrease the disease prevalence. In other words, the variable belongs to protective factor. It shows that the number of the children is not the risk factor of husband's participation as acceptor in family planning.

Bertrand Theory states that the number of the children is one factor influencing an individual participating in family planning [19]. Those who have more than 2 children tend to have the willingness to participate compared to those who have less than 2 children. The theory is not in line with the research result. Based on the research, fertile couples in Randusanga Kulon village who have less than 2 children tend to be the acceptor of family planning. It is in accordance with the national program, for the life of mother and children. Reproductive health is aimed at improving the health of mother and children [20].

\section{CONCLUSION}

There is significant relation between husbands' knowledge and participation in family planning in Randusanga Kulon Village, Brebes regency, Central Java. There is significant relation between husbands' education and participation in family planning in Randusanga Kulon village, Brebes Regency, Central Java. There is no significant relation between the number of children and husbands' participation in the family planning program in Randusanga Kulon, Brebes Regency, Central Java.

\section{REFERENCE}

[1] Sulistyawati, Ari. (2011). Family Planning Services. Jakarta. Salemba Medika.

[2] National Population and Family Planning Board (BKKBN). (2014), Percentage of Use of National Modern Contraception (in Bahasa: Badan Kependudukan dan Keluarga Berencana Nasional (BKKBN). (2014). Persentase Pemakaian Alat Kontrasepsi Modern Nasional, [online] Available: http://www.bkkbn.go.id/kependudukan/Pages/DataSurvey/SDKI/Fertilitas/Persentase_Pemakaian_Alat_Kontraseps i_Modern/Nasional.aspx

[3] National Population and Family Planning Board (in Bahasa: Badan Kependudukan dan Keluarga Berencana Nasional (BKKBN) Province Central Java. (2012). Results of Acquisition of New Kb Participants. [online] Available: http://jateng.bkkbn.go.id/data/default.aspx. (November 20, 2014).

[4] Berhane, A., Biadgilign, S., Amberbirs, A., Alemayehu, B., \& Deribes, K. (2011). Men's Knowledge and Spousal Communication about Modern Family Planning Methods in Ethiopia. African Journal of Reproductive Health December 2011; 15(4): $29-31$.

[5] Sya'roni. (2008). Low Male Participation in Brebes to Join KB. [online] Available: http://health.kompas.com/read/2008/01/18/21182656/, (March 3, 2014).

[6] Central Statistics Agency of Brebes District. (2014). Statistik Daerah Brebes District in 2013. [online] Available: http://brebeskab.bps.go.id/index.php?hal=publikasi_detil\&id=28, (Januari 3, 2015). 
[7] Central Statistics Agency of Brebes District. (2014). Brebes District in 2014. [online] Available: http://brebeskab.bps.go.id/index.php?hal=publikasi_detil\&id=28, (Januari 3, 2015). [18] Farkas A, Vanderberg R, Sucato GS, Miller E, Akers A,. 2015. Racial and Ethnic Differences in young Men's Sex and Contraceptive Education. J Adolesc Health. 56(4): 464-467.

[8] Notoatmodjo, S. (2003). Education and Behaviour Health. PT. Rineka Cipta, Jakarta.

[9] Anapah, Yoseph., Nabuasa, Engelina., Christina, R.N. (2007). The Influence of Knowledge, Attitudes and SocioCulture on Men's Participation in Using Family Planning In Kefamenanu Selatan Village District of North Central Timor. Journal MKM, Vol. 02 No. 01.

[10] Fridalni N Dan Kurniawan A. (2012). Relationship Level Knowledge, Attitude And Husband Support About KB With KB Participation By couples of childbearing age In Rw III Kelurahan Korong Gadang Work Area Puskesmas Kuranji Padang 2012. Thesis, STIKes Mercubaktijaya Padang.

[11] Listyani E, Nur W, Purwanti OS, (2012), Relationship of Husband Knowledge of Family Planning with Attitudes of Husbands in Family Planning In Mrisen Village, Juwiring District, Klaten District, Thesis, Faculty of Health University of Muhammadiyah Surakarta.

[12] Notoatmodjo, S., (2005), Health Research Methodology, PT. Rineka Cipta, Jakarta. Hal. 56.

[13] Shahamfar, Jafar., Kishore, Jugal \& Shokhvash, Behja, (2007), Effect Of Education Intervention On Male Participation In Family Planning In Iran, Health And Population Perspectives And Issues, Vol 30 No. 4, Hal 292294.

[14] Ahmad, (2009), Frequency and Determinant of Male Contraceptives in Indonesia, Jurnal Kesehatan Masyarakat Nasional. Vol. 03 No. 05.

[15] Hasian, Maretha. (2012), Factors Related to Men's Participation in Family Planning Program in Work Area of SEI Jang Tanjungpinang Community Health Center, 2012, Thesis, Universitas Indonesia, Depok, Hal 43-46.

[16] Rizkytama, A.A \& Indrawati, F. (2015). Relationship Knowledge, Perception, Social Culture With Active Role of Men in Vasectomy In District Paguyangan Brebes Year 2011-2012. Unnes Journal of Public Health, Vol 4 No. 1. Hal 48-53.

[17] Tilahun T, Gily C, Temmermen, Degomme O., (2015), Couple based family planning education: changes in male involvement and contraceptive use among married couples in Jimma Zone, Ethiopia, BMC Public Health, Vol. 15 : 682.

[18] Farkas A, Vanderberg R, Sucato GS, Miller E, Akers A, 2015, Racial and Ethnic Differences in young Men's Sex and Contraceptive Education, J. Adolesc. Health. 56(4): 464-467

[19] Berhane, A., Biadgilign, S., Amberbirs, A., Alemayehu, B., \& Deribes, K. (2011). Men's Knowledge and Spousal Communication about Modern Family Planning Methods in Ethiopia. African Journal of Reproductive Health December 2011: 15(4): 29 - 31 .

[20] Iyengar Sharad, Iyenger Kirti and Gupta V., 2009, Maternal Health: A Case Study of Rajasthan, J. Health Popul. Nutr. 27(2): 271-292 